\title{
The Power and the Passion: Igniting a Love of Reading through Literature Circles
}

\author{
Elizabeth Greef \\ with Yvonne Jenkins and Anthea Comer \\ St Andrew's Cathedral School \\ 474 Kent Street \\ Sydney NSW 2000 \\ Australia \\ egreef@sacs.nsw.edu.au
}

\begin{abstract}
This paper presents the simple but successful Literature Circles model at St Andrew's Cathedral School within the context of the importance of developing reading as a foundation for building knowledge. It covers crucial factors for success of the program, practicalities and procedures, the selection of books, and strategies for substantive discussion and a book list of the most successful titles.
\end{abstract}

Real reading goes to the heart of what it means to be human. Through reading we create ourselves. Through reading we reperceive the world and our relationship to it. Through reading we extend our capacity to create, to be part of the generative process of life.

Adapted quote from Senge (Dawson \& Fitzgerald, 1999, p. 1)

The adaptation of this quote reminds us what a foundational skill reading is. It has deep implications for our quality of life as human beings, our learning and our creativity. A reflection on reading adapted from Aidan Chambers (1983, pp. 6-7) spells out more precisely why so many people place a high value on reading literature:

Reading literature:

* helps extend our experience and knowledge of life;

- helps our personal growth - you discover yourself in literature and therefore learn to understand more about yourself;

* helps us to learn to spell and use our language better;

* entertains by passing the time pleasurably and in a socially acceptable way;

* helps our spiritual development;

* teaches us how - and how not to - behave;

* stretches the imagination;

* challenges and changes us;

* gets us into the closest possible contact with another person - the author;

* allows us to experience all kinds of possibilities from murder to childbirth, without suffering the consequences of undergoing the experiences in real life;

* is a game-playing activity in which we "try out" various possible solutions to life-problems and see how they might be worked out before having to tackle them in reality. 
A survey conducted in Australia in June 2001, A National Survey of Reading, Buying and Borrowing Books by A.C. Nielsen and reported by Ray Crotty, President of ASLA in its journal, produced interesting results - of the five most frequently mentioned leisure activities, watching television led the way, closely followed by reading for leisure. The other activities mentioned were using the Internet, computer games and movies but these were significantly behind in popularity. Another result indicated that $78 \%$ of the adult population read for pleasure every day or most days and that 8.1 hours were devoted to reading per week. (Crotty, 2001)

The recently relcased results of the PISA Project (The Programme for International Student Assessment) illuminate the performance of students in 32 countries in reading, scientific and matheriatical literacy. The assessment of students' reading literacy was achieved by measuring the students' ability "to construct, expand and reflect on the meaning of what they have read" in accordance with contemporary perspectives on reading. (OECD, 2000 , p. 6) The strategies of information retrieval, interpretation of meaning, reflecting on the meaning and evaluating it were assessed. One interesting finding was that student performance in reading scores was closely associated with students' utilization of school resources, particularly the school library, laboratories, computers and the Internet. (OECD, 2000) This can be seen as a significant validation of school libraries.

Reading is an essential as well as a pleasurable skill. We want our students to be lifelong learners, to feel and be empowered by their ability to read, to be well-equipped as citizens of a knowledge society. We know too from research that it is the quantity of reading which impacts most on academic achievement rather than the quality. We want our students to develop a passion for reading and to become discerning readers.

At St Andrew's Cathedral School we have had significant success with our Literature Circles program. It is well established, founded five and a half years ago by our Head Librarian Yvonne Jenkins who also initiated the program at Trinity Grammar School in 1995. St Andrew's Cathedral School has developed during that period, from being a boys' school of about 500 pupils to a school of 1000 students including girls in the final three years. The Literature Circles program has had a positive effect within the school and is widely supported by staff, parents and the Head of School. We have seen poor readers and non-readers become positive and even voracious readers and even budding novelists themselves.

Harvey Daniels (2002) has recently published the second edition of his book, Literature Circles: Voice and choice in book clubs and reading groups. According to this, research carried out in schools in Chicago between 1995-1998 linked literature circles to student achievement. Apparently test scores in the targeted schools outstripped other schools by $8-27$ percent.

\section{Why do it?}

There are many significant reasons to run a Literature Circles program:

* To encourage reading enjoyment

* To develop critical literacy

* To give students the opportunity to engage with texts

* To develop an emotional response

* To encourage a sense of empowerment in students through their choice of reading material and through skill-development 
* To hone a foundational lifelong skill

* To encourage cooperative learning

* To develop communication skills through sharing and substantive conversation

* To build on the English curriculum strands of reading, listening, speaking and writing

\section{What is it?}

Literature Circles is an intensive reading program which encourages the habit of daily reading for enjoyment, using attractive contemporary well-written books with a strong story. The process involves quiet reading in class and at home, discussions with the group reading the same book and writing the occasional response to the book.

\section{Features of Literature Circles at St Andrew's:}

The aim is enjoyment above all. Students have a choice from selected texts. These are all strong stories, carefully selected by the teacher librarian and known to interest boys. A word of experience here: "Old books from the English bookroom are a recipe for disaster." (Jenkins, 2001) The students form groups with others who have chosen the same book and read quietly and discuss until they finish the book and form other groups around other books. The class cycles through the following phases:

1. Silent reading

2. Discussion groups (with two or more groups per period with the teacher librarian as facilitator)

3. Writing responses (all students). The English teacher models silent reading with the main body of students.

\section{Making it happen: Practical organization}

A successful Literature Circles experience for students demands thoughtful and meticulous preparation and organization by the teacher librarians. At first, a two week block of all English lessons is negotiated with the English teacher and the seminar room is booked if possible as it is quieter for silent reading and the Literature Circles collection is housed there. The teacher librarian develops a "short list" of approximately six novels, which adolescent males enjoy and of which we have at least five or six copies each. If we are short of copies, we order more. Based on these novels the teacher librarian designs an attractive choice sheet with photocopied graphics, blurbs and excerpts from the text.

When the students arrive for the first class they find on their desks a sheet explaining Literature Circles, a colourful bookmark with ideas for points for discussion/questions and post-it notes to mark interesting points for discussion. With the Literature Circles collection are kept photocopy box lids with our handouts in them - Notes for Students explaining the program, Choice sheets, Student evaluation sheets, scrap paper for those who forget their reading journals, bookmarks, and packets of post-it notes. Discussion groups move out of the seminar room and sit in one of the comfortable areas; there is a semicircular glass alcove at the entrance with deep red armchairs and sofas and often discussions are held in that space. At least three times during the Literature Circles program students make written responses, which are marked. 
Procedure for secondary classes

\begin{tabular}{|c|c|}
\hline $\begin{array}{l}\text { Teacher } \\
\text { librarian } \\
\text { preparation }\end{array}$ & $\begin{array}{l}\text { Negotiation with classroom English teacher \& booking of } \\
\text { classes } \\
\text { * Careful selection of texts } \\
\text { Production of choice sheets with graphics, blurbs and extracts }\end{array}$ \\
\hline $\begin{array}{l}\text { Week } 1 \\
\text { Period } 1\end{array}$ & $\begin{array}{l}\text { A brisk pace is needed for the first class } \\
\text { Choice sheets, bookmark, \& post-it notes are on the tables } \\
\text { before each student } \\
\text { Teacher librarian takes control of class - brief introduction to } \\
\text { Literature Circles, what will happen, emphasizing enjoyment, } \\
\text { choice, silent reading, discussion, writing and what students } \\
\text { need to bring to each lesson } \\
\text { The teacher librarian introduces each book enthusiastically } \\
\text { Students look at the books on the list while the teacher librarian } \\
\text { sorts sheets into piles } \\
\text { The teacher librarian allocates books to students } \\
\text { Students borrow and join others with the same book } \\
\text { Any time left is for silent reading } \\
\text { others in their group where they will read to and record this in } \\
\text { their homework diaries. }\end{array}$ \\
\hline $\begin{array}{l}\text { Week } 1 \\
\text { Period } 2\end{array}$ & $\begin{array}{l}\text { During classes there will often silent reading in the library (to } \\
\text { develop the habit and reinforce the expectation) } \\
\text { The teacher librarian can hold a discussion group out in the } \\
\text { library if students in a group have read more than } 1 / 3 \text { of their } \\
\text { book } \\
\text { * The English teacher models silent reading with the class }\end{array}$ \\
\hline $\begin{array}{l}\text { Week } 1 \\
\text { Period } 3\end{array}$ & $\begin{array}{l}\text { At the start of the lesson check if any students have finished } \\
\text { reading their book. These students choose a new one from the } \\
\text { list and borrow. } \\
\text { Journal writing - for } 15+\text { minutes: personal response and } \\
\text { reference to the text is most valued; students can use post-it } \\
\text { notes and hints on the bookmark for ideas about what to write } \\
\text { and can illustrate their responses too } \\
\text { Discussion group/s facilitated by the teacher librarian }\end{array}$ \\
\hline $\begin{array}{l}\text { Week } 1 \\
\text { Period } 4\end{array}$ & $\begin{array}{l}\text { Two discussion groups one after another with teacher librarian } \\
\text { The rest read quietly with the classroom teacher in the library }\end{array}$ \\
\hline $\begin{array}{l}\text { Week } 2 \\
\text { Period } 5\end{array}$ & $\begin{array}{l}\text { Journal writing } \\
\text { Discussion groups } \\
\text { Silent reading }\end{array}$ \\
\hline $\begin{array}{l}\text { Week } 2 \\
\text { Period } 6\end{array}$ & $\begin{array}{l}\text { Discussion groups } \\
\text { Silent reading }\end{array}$ \\
\hline $\begin{array}{l}\text { Week } 2 \\
\text { Period } 7\end{array}$ & $\begin{array}{l}\text { Journal writing }-15+\text { mins } \\
\text { Ptudents fill out evaluation sheets (sometimes) } \\
\text { Presentation of Middle School reading list } \\
\text { - Silent reading if any time is left } \\
\text { Thank the class and stress your enjoyment of the time (if true) }\end{array}$ \\
\hline
\end{tabular}


This is a rough plan. However, the sessions are flexible and depend on the teacher librarian's choice of activities.

\section{Selection and introduction of books}

In seeking excellent texts for literature circles, the teacher librarians are in a continual process of seeking and reading books that will appeal strongly to their students. This involves listening to students about their reading discoveries and interests, reading book reviews and talking to booksellers and colleagues about books.

In the class the teacher librarians introduce and promote each book on the list, often reading a short extract to whet the students' appetites. It is vital the teacher librarian has read and is enthusiastic about the books so that they can be positive advocates of them and also be fully involved in discussion with the students.

\section{Written responses}

A written response is generally made about three times during the block of time. The questions on the bookmarks, which have been developed by my colleagues Yvonne Jenkins and Anthea Comer, can be used by students to help them choose where to place post-it notes as they read and as prompts for writing responses:

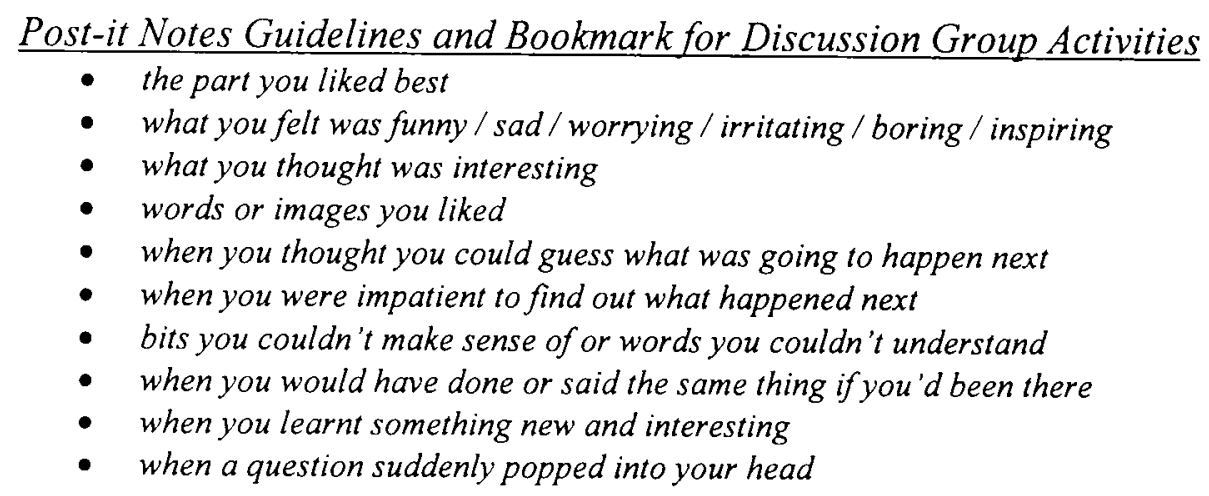

\section{Assessment}

There are many points of view on how to assess a dynamic process like Literature Circles. At St Andrew's we have found it works well to use the written responses as the basis for assessment as they generally correlate well to the students' contributions to discussion and immersion in the Literature Circles experience. The written responses are marked by the teacher librarian. Comments are positive and encouraging and seek to elicit higher order responses. If an attempt is made to express a response, students are always given a pass. The students receive the grade and a comment but the equivalent marks are recorded for the teacher on a class list. The grades and the equivalent marks are:

$$
\begin{aligned}
& \text { GRADE } \\
& \mathrm{HD}=\text { High Distinction } \\
& \mathrm{D}=\text { Distinction } \\
& \mathrm{C}++=\text { Credit }++ \\
& \mathrm{C}+=\text { Credit }+ \\
& \mathrm{C}=\text { Credit } \\
& \mathrm{P}=\text { Pass }
\end{aligned}
$$

\author{
CORRESPONDING MARK \\ 10 marks \\ 9 marks \\ 8 marks \\ 7 marks \\ 6 marks \\ 5 marks
}


Most teachers incorporate these marks into their class marks and this helps students put more effort into their response. The best responses may also be read out with the student's permission and are published by the teacher librarian in the school's weekly bulletin.

\section{Discussions}

The most popular and rewarding part of Literature Circles is usually the discussion groups. Many researchers endorse the value of critical discussion. Dr Stanley Pogrow of the University of Arizona has commented: "Engage in sophisticated conversation. The most underused technology in our classrooms is not computers, it's conversation. Teach children how to probe. Build a thinking environment. Engage in direct critical discussion and reflection on issues. I call it controlled floundering." (Quoted in Nelson Central School Newsletter, 2001). "Substantive conversation" is regarded as one of the hallmarks of intellectual quality, which is one of the four dimensions of Productive Pedagogy, expanded by academics at the University of Queensland in collaboration with other universities (Hayes, 2002). "Substantive conversation" occurs when students maintain a sustained dialogue among themselves with little teacher maintenance. We have never used predetermined roles for students in our discussions, such as the 'connector' and 'literary luminary' (Fitzgerald, 1997); a more free-flowing approach seems to work best in our school.

The discussions are held sitting in a circle on comfortable seating. The teacher librarian needs to be strongly affirming of students' contributions and can use these as springboards to further the discussion.

Some useful ground rules for discussion are:

* Permission to disagree with each other

* Listening to each other

* Speaking one at a time

* Knowing that there are no right or wrong answers, but OUR OWN response

- The need to include everyone in the discussion

(Ward, 1998)

\section{Discussion Questions}

A useful strategy for the teacher librarian to adopt is, when reading a book for Literature Circles, to fill in a small notebook or a card with notes about the book and to generate a list of up to 10 interpretive questions for discussion. These are the most helpful for Literature Circles.

There are three types of questions, all with a useful purpose:

Factual questions are direct with a simple correct answer. A couple can be useful at the start. Examples might begin with Where? When? Who?

Interpretive questions allow a variety of responses, viewpoints and interpretations and can generate significant discussion and lead to deeper understanding. Jamie McKenzie (1997) has written at length about the central importance of sound questioning for developing independent thinking and exploration and he believes that the prime questions for generating important thinking are: Why? How? and Which?

Evaluative questions encourage readers to express their feelings and thoughts about a book and judge it. These are best left towards the end of the discussion. (Ward, 1998) Often these types of questions might begin with Do you agree with... What would be... (Morino Institute, 2001) 


\section{Student evaluation of Literature Circles}

Sometimes, as well as encouraging free borrowing during the final session, we formally evaluate the program by asking students to respond anonymously to the following questions:

1. List the books you read and rate them from one to three stars.

2. What was the best thing about Literature Circles?

3. What was the worst thing about Literature Circles?

4. List books you think we could use in the program with the level they would be appropriate for.

5. Any other constructive suggestions as to how we could improve Literature Circles?

(Jenkins, 2001)

Some of the recent answers to Question 2 follow:

That I got to read books that I've never heard of before and that were good (Stormbreaker by Anthony Horowitz, Animal Farm, Lord of the flies by William Golding)

I liked the time to read which was like a break from school work and the talking about the book in a group. (Lockie Leonard human torpedo and Scumbuster, Hitchhiker's Guide to the Galaxy by Douglas Adams)

I enjoyed the talks the most. It was good because I could share my opinion about the book with others. (Hitchhiker's Guide to the Galaxy, The Restaurant at the end of the universe.)

\section{Other possibilities for Literature Circles}

A lower ability group has been involved with Literature Circles using books on tape with individual headphones borrowed from the Languages faculty. In each group each student had a copy of the book and their set of headphones was plugged into one cassette player together with up to five others listening to the same book.

Year 12 English teachers have asked the Head Librarian over several years to run a Literature Circle type discussion with their students on senior texts such as Michael Ondaatje's In the skin of a lion.

\section{Critical factors}

There are a number of critical contributing factors to the success of Literature Circles at St Andrew's Cathedral School
* Selection of strong stories
* Thoughtful introduction of texts to whet the appetite
* Teacher librarian leadership of program and pacing of elements
- Support of English teacher, faculty and Head of School
* Teacher librarian must have read the book and be an enthusiastic and positive advocate of it
* Flexibility
- Open relaxed respectful atmosphere in discussions
* Motivation provided by best written responses being published in the weekly bulletin
* A library environment conducive to reading 


\section{Results of the Literature Circles Program}

It has become "cool" to read at St Andrew's. The atmosphere of mutual enjoyment of books and the opportunities for discussion spill over into all places in the school - chatting with students about their reading at lunchtime, sharing our discoveries in the corridor on the way to roll call, discussing our reading at sport, consulting each other about recommendations for reading. There are also appreciative phone calls and letters from parents about the positive effect Literature Circles has had on their sons and parent-initiated consultation about their child's reading.

One parent wrote the following paragraph in a letter of appreciation:

"It is a delight to see R. spending hours reading books of substance and quality and thoroughly enjoying it. While we are a family who loves books, it is R's experience of Literature Circles which has really kick-started him into this mode." (Comer, 2001)

The whole school community is able to enjoy the perceptive comments made by some students in their written responses when they are published in the weekly newsletter. These enthusiastic peer recommendations also motivate other students to read those books. There is a natural and warm continuing dialogue about books between students and library staff, initiated and nurtured through Literature Circles.

\section{The end result}

It is our hope that the result of this process is many passionate, empowered and independent readers.

"If reading is about mind journeys, teaching reading is outfitting the travelers, modeling how to use the map, demonstrating the key and legend, supporting the travelers as they lose their way and take circuitous routes, until, ultimately, it's the child and the map together and they are off on their own." (Keene and Zimmerman, quoted in Daniels, 2002)

\section{Credits}

The Literature Circles Program at St Andrew's Cathedral School has been introduced and honed through the inspirational leadership of Yvonne Jenkins, Head Librarian. Anthea Comer as the primary teacher librarian has adapted the program to suit the primary students. Its success is also due to the enthusiastic support of the Head of School, Phillip Heath, the Head of English, Christine Crump, the Head of Primary, Merilyn Smith and the teachers, particularly of the English Department.

\section{Bibliography}

Chambers, A. (1983). Introducing books to children. Heinemann Educational: London.

Comer, A. (2001). Literature Circles in the Primary School. [Unpublished article]

Crotty, R. (2001). President's Report. ASLA NSW Teacher \& Librarian, 144, 3.

Daniels, H. (2002). Literature Circles: Voice and choice in book clubs and reading groups. (Online). www.stenhouse.com/0333.htm 
Dawson, D. \& Fitzgerald, L. (1999). Literature Circles: Reading in action. Centre for Information Studies, CSU: Wagga Wagga, NSW.

Fitzgerald, L. (1997). Literature Circles: Linking literature and information literacy. Scan, 16, $3,17-20$.

Hayes, D. (2002) Productive pedagogies. Presentation at St Andrew's Cathedral School.

Jenkins, Y. (2001). Literature Circles at SACS 2001. [Unpublished article]

Morino Institute. (2001) The Art of Asking Good Questions. (Online) http://www.youthlearn.org/learning/teaching/questions.asp

Nelson Central School Newsletter. (2001). (Online) http://www.nelsoncentral.school.nz/newsletters/09.html

OECD. (2000). Knowledge and skills for life: First results from PISA 2000: Executive summary. (Online). http://www.pisa.oecd.org/Docs/Download/PISAExeSummary.pdf

Ward, C. (1998). Having their say: How to lead great book discussions with children. School Library Journal, April 1998.

SITES TO VISIT ON QUESTIONING:

Sites on questioning, researching and leading discussions by Jamie McKenzie:

Questions and questioning: The most powerful technologies of all. http://emifyes.iserver.net/fromnow/nov99/techquest.html

A questioning toolkit continued. http://emifyes.iserver.net/fromnow/nov97/toolkit3.html

The question is the answer: Creating research programs for an age of information http://emifyes.iserver.net/fromnow/oct97/question.html

Questioning.org

http://www.questioning.org/

Preparing questions for a book discussion

http://www.northstarnet.org/prkhome/library/bkdiscques.html olbox.html

\section{LITERATURE CIRCLES:}

www.literaturecircles.com - online resource; book reviews; teacher idea exchange

Literature Circles - Harvey Daniels

www.stenhouse.com/0333.htm - online version of the book 
THE MOST SUCCESSFUL

SECONDARY LITERATURE CIRCLES TITLES at St Andrew's Cathedral School

We have many multiple copies of books in our Literature Circles collection but these are the ones we find most successful.

$*=$ for better readers

\begin{tabular}{|l|l|}
\hline YEAR 7 & YEAR 9 \\
(13 year olds) & (15 year olds) \\
\hline Stormbreaker - Anthony Horowitz & Ice Station - Matthew Reilly \\
\hline Point Blanc - Anthony Horowitz & Area 7 - Matthew Reilly \\
\hline $\begin{array}{l}\text { Forests of silence - Emily Rodda } \\
\text { Deltora Quest series }\end{array}$ & $\begin{array}{l}\text { Ender's game - Orson Scott Card } \\
\text { \& series * }\end{array}$ \\
\hline Redwall series- Brian Jacques & Dogs - Bill Condon \\
\hline Reptile Room - Lemony Snicket & The outsiders - S.E. Hinton \\
\hline Remote Man - Elizabeth Honey * & Lord of the flies - William Golding \\
\hline Hatchet - Gary Paulsen & Go ask Alice * \\
\hline Lockie Leonard Scumbuster - T. Winton & Animal farm - George Orwell * \\
\hline $\begin{array}{l}\text { Pagan's crusade \& series - } \\
\text { Catherine Jinks * }\end{array}$ & $\begin{array}{l}\text { Hitchhiker's guide to the } \\
\text { Douglas Adams * }\end{array}$ \\
\hline Harry Potter series - J.K. Rowling & The War series - John Marsden \\
\hline Space Demons - G. Rubinstein & Airframe - Michael Crichton * \\
\hline Northern lights - Philip Pullman * & Lord of the Rings - J.R.R. Tolkien * \\
\hline & Blackwater - Eve Bunting \\
\hline & Black Hawk Down - Mark Bowden \\
\hline & \\
\hline $\begin{array}{l}\text { YEAR 8 } \\
\text { (14 year olds) }\end{array}$ & $\begin{array}{l}\text { PRIMARY } \\
\text { (8-12 YEAR OLDS) }\end{array}$ \\
\hline Artemis Fowl - Eoin Colfer & Merryll of the stones - Brian Caswell 1. \\
\hline Point Blanc - Anthony Horowitz & Wizard of Earthsea - Ursula Le Guin 1. \\
\hline Contest - Matthew Reilly & Master of the grove - Victor Kelleher 1. \\
\hline Blackwater - Eve Bunting & Redwall - Brian Jacques 1. \\
\hline $\begin{array}{l}\text { Deadly Unna? - Phillip Gwynne } \\
\text { Nukkin' Ya }\end{array}$ & $\begin{array}{l}\text { Space demons - G. Rubinstein 2. } \\
\text { Deltora Quest - Emily Rodda 2. }\end{array}$ \\
\hline Hatchet - Gary Paulsen & Mrs Frisby \& the rats of Nimh - RO'Brien \\
\hline $\begin{array}{l}\text { Tomorrow when the war began - John } \\
\text { Marsden }\end{array}$ & $\begin{array}{l}\text { Don't pat the wombat - E. Honey 2. } \\
\text { Toad rage - Morris Gleitsman 2. }\end{array}$ \\
\hline Ghost Byte - John Larkin & Driving a bargain - Fleur Beale 3. \\
\hline Lockie Leonard Human Torpedo \& L.L. & $\begin{array}{l}\text { Matilda - Roald Dahl 3. } \\
\text { The twits - Roald Dahl 4. }\end{array}$ \\
\hline Airframe - Michael Crichton * & Tashi and the giants - A, Fienberg 4. \\
\hline Sophie's world - Jostein Gaarder * & Victor's Quest - Pamela Freeman 4. \\
\hline Black Hawk Down - Mark Bowden * & 3. - developing readers \\
\hline
\end{tabular}

Elizabeth Greef, Yvonne Jenkins \& Anthea Comer 